\title{
Diagnosis, follow-up and treatment of herpes simplex virus encephalitis in intensive care unit: Case report
}

\author{
Herpes simpleks virüs ensefalitinin yoğun bakımda tanı, takip ve tedavisi: Olgu \\ sunumu
}

\author{
Kenan Kaygusuz, Cevdet Düger*, İclal Özdemir Kol, Ahmet Cemil İsbir, Sinan \\ Gürsoy, Caner Mimaroğlu
}

Anesteziyoloji ve Reanimasyon Anabilim Dalı (Assoc. Prof. K. Kaygusuz, MD, Assist. Prof. C. Düger, MD, Assoc. Prof. İ. Özdemir Kol, MD, Assist. Prof. A. C. İsbir, MD, Prof. S. Gürsoy, MD, Prof. C. Mimaroğlu, MD), Cumhuriyet University School of Medicine, TR-58140 Sivas

\begin{abstract}
Although its treatment is available, complication incidence, probability of permanent neurologic sequel and rate of mortality are still high in herpes simplex virus encephalitis (HSVE). Early diagnosis and prompt antiviral therapy are essential to improve prognosis and to prevent severe neurologic complications. Here we wanted to present a 46 years old female patient hospitalized at the infectious diseases service with the pre-diagnoses of tuberculosis meningoencephalitis and herpes simplex virus encephalitis (HSVE) was then admitted to intensive care unit upon loss of consciousness and respiratory failure. The patient was discharged at the $102^{\text {nd }}$ day. We believe that early diagnosis and treatment of HSVE cases at intensive care units with a multidisciplinary approach may decrease morbidity and mortality significantly.
\end{abstract}

Keywords: Herpes simplex virus, encephalitis, intensive care unit

\section{Özet}

Tedavisinin mevcut olmasına rağmen herpes simplex virüs ensefalitinin komplikasyon insidans1, kalıcı nörolojik sekel olasılığı ve mortalitesi halen yüksek oranlardadır. Erken tanı ve hızlı antiviral tedavi prognozun düzelmesi ve ciddi nörolojik komplikasyonların önlenmesi için esastır. Tüberküloz meningoensefaliti ve herpes simplex virüs ensefaliti ön tanıları ile enfeksiyon hastalıkları servisine yatırılan 46 yaşındaki bayan hasta, bilinç kaybı ve solunum yetmezliği gelişmesi üzerine yoğun bakım ünitesine alındı. Hasta yatışının 102. gününde taburcu edildi. HSVE olgularının yoğun bakım ünitelerinde, multidisipliner tedavi yaklaşımlarıyla erken tanı ve tedavisinin morbidite ve mortaliteyi belirgin olarak azaltabileceğini düşünmekteyiz.

Anahtar sözcükler: Herpes simpleks virus, ensefalit, yoğun bakım ünitesi

Geliş tarihi/Received: September 24, 2012; Kabul tarihi/Accepted: November 7, 2012

\section{*Corresponding author:}

Dr. Cevdet Düger, Anesteziyoloji ve Reanimasyon Anabilim Dalı Cumhuriyet Üniversitesi Tıp Fakültesi, TR-58140 Sivas. E-mail: cevdetduger@gmail.com

\section{Introduction}

Herpes simplex virus (HSV) is an enveloped virus with a double-stranded DNA and its infections are commonly observed in human population. Two strains, HSV-1 and HSV-2, have been identified [1]. HSV may cause various inflammatory neurological diseases. Herpes simplex virus encephalitis (HSVE) is the most commonly encountered one among these diseases. Although HSVE is rare, it has a high morbidity and mortality rate [2]. 
Although its treatment is available, complication incidence, probability of permanent neurologic sequel and rate of mortality are still high in HSVE. This is mainly related with wrong diagnosis, etiological misidentification and delay in treatment. Detecting abnormal temporal lobe activity by EEG supports HSVE diagnosis. Early diagnosis and prompt antiviral therapy are essential to improve prognosis and to prevent severe neurological complications [3, 4].

In the absence of antiviral therapy, mortality rate is more than $70 \%$, prognosis is poor and only $2.5 \%$ of the survivors regain normal neurologic functions [2].

HSVE patients usually present with fever, headache, seizures and various mental complaints. Detecting cellular and biochemical alterations in cerebral spinal fluid (CSF) increases the diagnostic value of suspected central nervous system infection. In cerebral spinal fluid of patients with HSVE, findings include mononuclear predominance of cells, erythrocytes, a variably elevated protein and a normal glucose level. Due to hemorrhagic and necrotizing nature of the infection, CSF often contains erythrocytes [5].

In a patient having clinical features such as fever, mental confusion, focal neurological findings suggesting encephalitis, diagnosis can be supported by laboratory findings; however, detection of specific viral antigen in brain cell culture or HSV DNA by PCR are required to make a definite diagnosis of HSVE. Brain biopsy is $96 \%$ sensitive and $100 \%$ specific in HSVE; however it is not indicated when CSF abnormalities are atypical, CSF PCR and antibody tests are negative and MR and EEG findings are nonspecific [6].

\section{Case report}

A 46 years old female patient brought to the emergency service with fever, nausea, headache and contraction all over the body was admitted to the infectious diseases service with the pre-diagnosis of tuberculosis meningoencephalitis and HSVE. The patient was then admitted to the intensive care unit with loss of consciousness and respiratory failure. Glasgow Coma Scale (GCS) of the intubated patient being ventilated in SIMV mode in the intensive care unit was determined to be 6-7. Central venous pressure catheter, arterial catheter and urinary catheter were placed. Apachi II score of the patient was 23 and the mortality rate was found to be $50 \%$.

On the second day of her hospitalization, an empirical treatment with meropenem $3 \times 1$ gr and acyclovir $3 \times 750 \mathrm{mg}$ (as HSVE could not be eliminated) and anti-tuberculosis therapy (isoniazid $1 \times 300 \mathrm{mg}$, rifampicin $1 \times 500 \mathrm{mg}$, pyrazinamide $1 \times 3 \mathrm{gr}$, ethambutol $1 \times 1.5 \mathrm{gr}$ ) were initiated. Anti-tuberculosis treatment was discontinued as CSF cultures were found to be negative. CSF chemical analysis revealed increased protein and glucose and decreased LDH (Table 1).

Table 1. CSF biochemistry results.

\begin{tabular}{lll}
\hline CSF & Result & Normal \\
\hline Protein & $65 \mathrm{mg} / \mathrm{Dl}$ & $15-45$ \\
Glucose & $88 \mathrm{mg} / \mathrm{Dl}$ & $40-70$ \\
LDH & $42 \mathrm{IU} / \mathrm{L}$ & $125-240$ \\
\hline
\end{tabular}

During the term of hospitalization, blood, urine and sputum microscopies and cultures were collected and adequate anti-biotherapy was administered based on the results. CVP catheter was replaced every 30 days unless a complication was observed. On the $7^{\text {th }}$ day of hospitalization, a tracheostomy procedure was performed upon indication of tracheostomy to prevent complications of endotracheal tube.

Respiratory rate, tidal volume, PEEP and respiratory mode adjustments of the mechanical ventilator were made based on the arterial blood gas $(\mathrm{ABG})$ analysis results. Controlled mechanical ventilation was applied when oxygenation failure occurred. However, SIMV mode in which the patient could breathe spontaneously was preferred. In order to 
minimise risks such as deep vein thrombosis and stress ulcer at intensive care unit, an adjunctive treatment was administered with enoxaparin sodium, famotidine, metoclopramide and sucralphate.

Brain scans obtained on spiral computed tomography on the $5^{\text {th }}, 15^{\text {th }}$ and $30^{\text {th }}$ days of hospitalization were normal. Evaluation of the brain scans obtained on contrast and noncontrast spiral computed tomography on the $45^{\text {th }}$ day, where the patient was still unconscious, revealed patchy bilateral temporal hypodense areas showing moderate contrast involvement after intravenous contrast medium administration, especially on the right side (HSVE finding). EEG revealed diffuse slow wave activities, pointing out a moderate cerebral dysfunction and which can be observed when brain is affected diffusely (toxic, metabolic, degenerative, hypoxic, infectious etc.). At the end of the neurological evaluation, phenytoin sodium $3 \times 100 \mathrm{mg}$ was initiated as an antiepileptic therapy.

Starting from the $20^{\text {th }}$ day of hospitalization, the patient regained consciousness at intervals and her GCS was between $9-11$. On the $30^{\text {th }}$ day of her hospitalization, a physical examination performed when the patient was conscious revealed $3 / 5$ loss of power in only the left upper extremity and this was thought to be associated with the lesion on the right temporal area. In order to prevent development of spasticity, baclofen $3 \times 10 \mathrm{mg}$, tyzanidine HCL 1x6 mg and a cold therapy with cold packs to all extremities for 20 minutes which was followed by at least half an hour passive exercise were administered.

On the $85^{\text {th }}$ day of her hospitalization, the patient was allocated to undergo weaning upon observing that her vital findings were stable, GCS was 12-13, she had no infection, she had a respiratory frequency of $15-20 / \mathrm{min}$. at spontaneous mode of mechanical ventilation, tidal volume was 350-400 mL and $\mathrm{pH}: 7.51, \mathrm{pO}_{2}: 96, \mathrm{pCO} 2: 33.4, \mathrm{HCO}_{3}: 28, \mathrm{BE}: 4.3$ and $\mathrm{SpO}_{2}$ : $98.7 \%$ in $\mathrm{ABG}$ analysis. The patient was disconnected from ventilation with Ayre's T-piece a few times a day as tolerated by her. "Meanwhile, ABG analysis and $\mathrm{SpO}_{2}$ were followed-up frequently. Patient was immediately supported by mechanical ventilation in spontaneous mode when she got tired or when ABG or saturation of peripheral $\mathrm{O}_{2}$ were not within the target range. At the end of 10 days, the patient was followed-up for 3 days disconnected from mechanical ventilation with Ayre's T-piece. It was observed that the patient had sufficient spontaneous respiration through tracheostomy cannula using the oxygen in the environment. At the end of 3 days, tracheostomy of the patient was closed. Incision of the patient having tracheostomy for 85 days healed without any problem 5 days after removing the cannula. Neurological examination performed on the $102^{\text {th }}$ day of her hospitalization revealed $2 / 5$ loss of power in left upper extremity and 1-2/5 loss of power in left lower extremity. The patient was followed-up and treated at intensive care unit for 102 days and was then discharged from the hospital with only some loss of power in extremities.

\section{Discussion}

Although its treatment is available, complication incidence, probability of permanent neurologic sequel and rate of mortality are still high in HSVE. Although treatment was initiated early in the present patient, neurological sequels observed were $2 / 5$ loss of power in left upper extremity and 1-2/5 loss of power in left lower extremity. This is related with etiological misidentification and delay in treatment [5].

Optimal timing of tracheostomy is a disputable issue. In the present case, in line with the literature, decision of tracheostomy was taken on the $7^{\text {th }}$ day of intubation. If possible, this process can be delayed in intubated patients to allow extubation or should be performed early in order to prevent long term complications (intubation granuloma, posterior commissure stenosis, edema and subglottic stenosis). The risk of complications due to endotracheal intubation is proportionate to the duration of intubation [7]. 
Spasticity is a common problem and if not or badly treated, it may easily cause joint contractor which restricts maintaining the right posture for eating, communicating and performing many other daily life activities respectively. Muscle spasms may cause pain and may be one of the basic predisposing factors for pressure sores. Cold application may inhibit a spastic muscle. It has a short term effect on spasticity which lasts nearly half an hour after a 15-20 minutes application. Thus, the effect of this technique alone does not last long. It is just an adjunctive therapy which is beneficial to active stretching and functional exercises [8]. In our case, central and peripheral muscle relaxants and cold therapy were administered. Positioning and passive exercises were performed regularly every two hours.

Not washing catheter lumen after treatment, nutritions and oily emulsions prepared a few days before treatment and administering antibiotics incompatible with calcium salts, sodium bicarbonate and heparin cause precipitate and clot formation. Unlike thrombus which forms slowly, precipitates occur suddenly. In order to prevent formation of precipitate and clot, catheter lumen should be pressure washed using an adequate solution [9]. In the present case, antisepsis was undertaken with great care in any procedure involving catheter. Catheter was replaced when the patient had fever and culture was taken from the insertion site of the catheter. Catheter was washed using $0.9 \% \mathrm{NaCl}$ solution after parenteral feeding.

Today, a critical disease is regarded as the most important stress for a person, and it is thought that pain, fear and anxiety occurring for various reasons at intensive care units affect mortality seriously by intensifying the neuroendocrine stress response of the organism. For this reason, sedation and analgesia practice is accepted as one of the most important step required to be included in the treatment protocol of an intensive care unit patient [10]. For sedation, midazolam infusion was used in in our case as midazolam is a short acting anticonvulsant agent having antegrade amnesic properties.

Having EEG findings with abnormal activities at the areas same as those at temporal lobe findings support HSVE diagnosis. Imaging may reveal patchy hypodense areas in the brain, especially in bilateral temporal areas. It has been found that there is a close relation between EEG findings and clinical results of cerebral involvement and that burst suppression pattern or periodic epileptiform discharges are poor prognostic markers. It is known that imaging studies and EEG findings may provide useful information to determine diagnosis and prognosis of HSVE [1]. In the present case, findings obtained in computed tomography and EEG were consistent with HSVE. Temporal lobe brain biopsy was not done as the clinical condition of the patient improved.

However, as unilateral or bilateral temporal and/or frontal lobe involvement is typical in HSVE, an active therapy with antiviral agents is suggested. Besides imaging methods, other laboratory findings that support HSVE diagnosis include diffuse wave deceleration in EEG or focal changes in temporal regions, background slowing and periodic complexes [12].

CSF culture has a low importance in diagnosing HSV infections in the brain. Detecting cellular and biochemical alterations in CSF increases the diagnostic value of suspected central nerve system infection. In cerebral spinal fluid of patients with HSVE, findings include mononuclear predominance of cells, erythrocytes, a variably elevated protein and a normal glucose level [13]. CSF culture of the present patient revealed increased CSF protein and glucose and decreased CSF LDH.

In HSVE, there is a high risk of mortality. However, its mortality decreases significantly by acyclovir therapy and multidisciplinary treatment approaches. If extubation is not planned at an early stage in the intensive care unit, a tracheostomy should be made as early as possible. Enteral or parenteral feeding of intensive care patients is an important parameter affecting morbidity and mortality positively. Infection is the most frequently encountered reason for mortality in intensive care patients. However, infections can be 
prevented by hygiene compliance of intensive care unit staff, an empirical treatment even in the tiniest suspicion of infection and an effective anti-biotherapy after culture results.

We believe that early diagnosis and treatment of HSVE cases at intensive care units with a multidisciplinary approach may decrease morbidity and mortality significantly.

\section{References}

1. Kohl S. Herpes Simplex Virus. In: Behrman RE, Kliegman RM, Jenson HB (Editors). Nelson Textbook of Pediatrics, Philadelphia: Saunders Company, 2004: 1051-7.

2. Tyler KL. Herpes simplex virus infections of the central nervous system: encephalitis and meningitis, including Mollaret's. Herpes 2004; 11: 57-64.

3. Kuhn J, Wieland U, Muller W, Bewermeyer H. Herpes simplex virus type 1 encephalitis. Med Klin (Munich) 2004; 99: 441-6.

4. Ladapo TA, Oyenusi E, Lesi F. Herpes simplex encephalitis. Niger J Clin Pract 2011; 14: 112-4.

5. Eisenstein LE, Calio AJ, Cunha BA. Herpes simplex (HSV-1) aseptic meningitis. Heart Lung 2004; 33: 196-7.

6. Whitley RJ. Viral infections of the central nervous system. In: Cohen J, Powderly WG, eds. Infectious Diseases. 2nd ed. London: Mosby, 2004: 267-77.

7. Groves DS, Durbin CG Jr. Tracheostomy in the critically ill: indications, timing and techniques. Curr Opin Crit Care 2007; 13: 90-7.

8. Gündüz Ş. Spinal Spastisite Tedavisinde Yenilikler. FTR Dergisi 1999; 5: 45-56.

9. Polderman KH, Girbes A. Central venous catheter use. Intensive Care Med 2002; 28: 1-17.

10. Demirağ K. Yoğun bakımda sedasyon. Türk Anesteziyoloji ve Reanimasyon Derneği Dergisi 2004; 18-23.

11. Jha S, Patel R, Yadav RK, Kumar V. Clinical spectrum, pitfalls in diagnosis and therapeutic implications in herpes simplex encephalitis. J Assoc Physicians India 2004; 52: 24-6.

12. Majumdar I, Hartley-McAndrew ME, Weinstock AL. Central nervous system herpes simplex virus infection in afebrile children with seizures. J Child Neurol 2012; 27: 445-50.

13. Boivin G. Diagnosis of herpes virus infections of the central nervous system. Herpes 2004; 11: 48-56. 